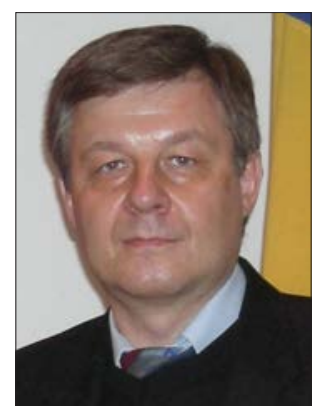

Olexandr V. Shchedrolosiev

Щедролосєв Олександр Вікторович

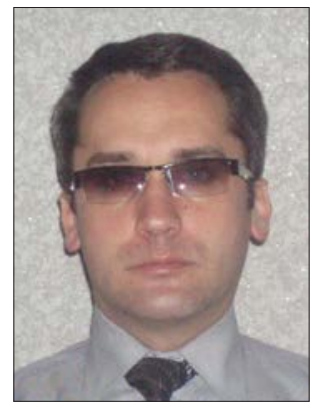

Stanislav V. Terlych

Терлич Станіслав Володимирович

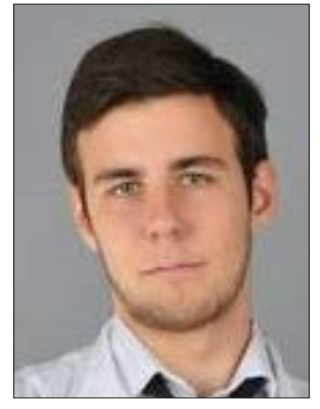

Mykola 0. Shchedrolosiev Щедролосєв Микола Олександрович

УДК 629.514

\title{
THE CURRENT STATUS AND PROSPECTS OF MODULAR HOUSEBOATS CONSTRUCTION AND TECHNICAL EXPLOITATION
}

\section{СУЧАСНИЙ СТАН І ПЕРСПЕКТИВИ ПОБУДОВИ ТА ЕКСПЛУАТАЦІЇ МОДУЛЬНИХ ХАУСБОТІВ}

DOI https:// doi.org/ 10.15589/smi2019.2(12).2

\author{
Olexandr V. Shchedrolosiev Щедролосєв Олександр Вікторович, \\ докт. техн. наук, проф. \\ aleksandr.schedrolosev@nuos.edu.ua \\ ORCID: 0000-0001-7972-3882 \\ Stanislav V. Terlych \\ Терлич Станіслав Володимирович, канд. техн. наук, доц. \\ slavus.ter@gmail.com \\ ORCID: 0000-0002-6044-3087
}

Mykola O. Shchedrolosiev Щедролосєв Микола Олександрович, магістрант as.seisnuos2017@gmail.com

Admiral Makarov National University of Shipbuilding, Mykolayiv

Національний університет кораблебудування імені адмірала Макарова, м. Миколаїв

Abstract. Priority plans include designing, constructing and operating houses and those facilities, which are based on water, above water and water. The classification of floating objects at the deposits of the sea is indicated on the surface of the water, the method of positioning is visible on the ground and the construction materials, as well as the shape of the floating equipment. The theoretical basis was science robots in the project hall and the house and house construction, debarked, pontoon; regulatory framework for the Navigation Register of Ukraine, as well as the availability of a modular design and the design and technology of floating and coastal equipment. The meta-duplication of the viability of the project design and technology of the viability of the service, adapted for the Ukrainian water supply. Task, for viral duplication, foregoing supplementary tendency for projecting a wake-up call on a plumbing base; the provision of substantially substantiated project design for watershed infrastructure; providing sound and visual design and visualization and typology of real-world classifications; a description of the functional-planning organ of the house. It has been found that in the $21 \mathrm{st}$ century, floating and water houses are a worthy alternative to land-based residential buildings as environmentally viable buildings in major cities. Some German cities (including Hamburg and Rostock) are promoting a model of living on the water, based on the experience of the Netherlands, offering a lifestyle closer to nature. The possibility of constructing houses on piles and pontoons in those regions of Ukraine where floods and floods are systematic (Vinnitsa, Khmelnitsky, Volyn' regions) is an alternative solution in the fight against the water element. The world experience of construction of residential buildings on the water is analyzed and the stages of their formation are revealed. The classification of structures on water, above water and under water has been developed depending on the type of superstructures, the principle of water support and the method of implementation.

Key words: houseboat, floating equipment, hydraulic engineering constructions, vocal analysis.

Анотація. У дослідженні розглянуто сучасні тенденції проектування, конструювання та будівництва хаусботів (плавучих будинків) та інших об'єктів, які базуються на воді, над водою та під водою. Наведено класифікацію плавучих об'єктів залежно від розташування, відносно поверхні водоймища, способу позиціонування, відносно грунту та конструктивних матеріалів, які використовуються під час формування плавучої споруди. Теоретичною базою послужили наукові роботи в галузі проектування та конструювання хаусботів, дебаркадерів, понтонів; нормативно-правова база Регістру судноплавства України, а також дослідження щодо модульного формування та конструктивно-технологічних рішень плавучих та берегових споруд. Мета дослідження полягає у виявленні особливостей проектно-конструкторських та технологічних особливостей виготовлення хаусботів, адаптованих під водоймища України. Задачі, які вирішуються під час дослідження, передбачають:

- виявлення сучасних тенденцій проектування та будування споруд на плавучій основі; - проведення аналізу сучасного та закордонного досвіду проектування та будування інфраструктури на плавучих спорудах; 
- враховуючи узагальнений досвід проектування та будування хаусботів, виявлення їх типологічних особливостей та створення їх класифікації;

- опис особливостей функціонально-планувальної організації хаусботів.

3'ясовано, що у XXI столітті плавучі та водні будинки є достойною альтернативою житлових будівель «на суші» як екологічно життєздатних споруд у крупних містах. Деякі німецькі міста (зокрема Гамбург та Росток) просувають модель проживання на воді, грунтуючись на досвіді Нідерландів, запропоновуючи спосіб життя більш близький до природи. Можливість побудови будинків на палях та понтонах у тих регіонах України, де паводки та повені мають систематичний характер (Вінницька, Хмельницька, Волинська області), $є$ альтернативним рішенням у боротьбі з водною стихією. Проаналізовано світовий досвід будівництва житлових споруд на воді та виявлено етапи їх формування. Розроблено класифікацію споруд на воді, над водою та під водою залежно від типу надбудов, принципу підтримки їх на воді та способу виконання.

Ключові слова: хаусбот, плавучі споруди, гідротехнічні конструкції, порівняльний аналіз.

\section{References}

[1] Hellweg, U. (2012) Floating Homes at Rummelsburg Day in Berlin. Wasserstadt. Gmbh. 32-38.

[2] Kendall, S. (2015) Residential open building? Jonathan Teicher. London: E\&FN SPON. 23-26.

[3] Pravila klassifikacii i postrojki malyh sudov (2015) [Rules of classifikcation and building of small vessels]. Kiev : Ukrainian Register of shipping [in Russian].

[4] Shehorkina, S.E. (2013) Racionalnoe proektirovanie konstrukcij maloetazhnyh zhilyh zdanij na vode [The rational designing of low-rise residential buildings on the water] The dissertation for the degree of candidate of technical sciences. Dnepropetrovsk. 168 p [in Russian].

[5] Savitsky, N.V. \& Shekhorkina, S.Ye. (2013) Plavucha platforma [Floating platform]. Invention patent of Ukraine. № u201302998. declared 11.03.2013; published 27.08.2013 [in Ukrainian].

[6] Ekonomov, I.S. (2010) Principy formirovaniya maloetazhnyh zhilyh obektov na vode: [The principles of the formation of low-rise objects on the water] The dissertation for the degree of candidate of architecture. Moscow. 2010. $131 \mathrm{p}$ [in Russian].

[7] Ekonomov, I.S. (2010) Sovremennye sposoby stroitelstva arhitekturnyh obektov na vode [Modern methods of building objects on the water]. Materials of the scientific and practical conference. 238-244 [in Russian].

[8] Koekoek, M. Connecting Modular Floating Structures : A General Survey and Structural Design of a Modular Floating Pavilion URL: http://repository.tudelft.nl/view/ir/uuid:33b59201-1718-4dda-98f8-ee16d5b7c023/pdf. (access date 12.11.2019)

[9] Sluckij, N. G. (2006) «Palada». Novye gorizonty prezhnej specializacii ["Pallada”. New horizons of previous specialization]. Shipbuilding \& Shiprepair. Odessa. №8. 8-9.

[10] Sluckij, N.G., Rashkovsky, A.S. \& Ermakov, D.V. (2007) Ekonomicheskaya effektivnost stroitelstva i ekspluatacii kompozitnyh plavuchih dokov bolshoj podemnoj sily [Cost-effective construction and operation of floating docks of high lift] Economics: problems of theory and practice. Donetsk. \# 232, Volume III. 614-621 [in Russian].

[11] Rashkovsjkyj O. S. et al. (2015) Proektuvannja, tekhnologhija i orghanizacija pobudovy kompozytnykh plavuchykh dokiv. [Design, technology and organization for building composite floating docks]. Mykolajiv, RAL-polighrafija. 254 p. [in Russian].

[12] Shedrolosiev, O.V., Terlych, S.V. \& Shedrolosiev M.O. (2019) Doslidzhennya hodovih yakostej plavuchogo budinku [Research on the driving performance of a houseboat] X International science-practical conference "Advanced energy installations for transport, technology and ownership for servicing (SEUTTO-2019)" (11-12 sept. 2019). Kherson. 238-240 [in Ukrainian].

[13] Shedrolosev, A.V. \& Terlych, S.V. (2016) Kompleksnoe usovershenstvovanie tehnologij oborudovaniya i otdelki pomeshenij nesamohodnyh sudov i drugih plavuchih sooruzhenij [Comprehensive improvement of equipment technology and decoration of non-self-propelled vessels and other floating structures]. Collection of scientific papers of Azerbaijan State Marine Asademu \#2. Baki. [in Russian] 50-56.

[14] Shedrolosyev, O. V. \& Terlych, S.V.(2008) Suchasnij stan modulnogo formuvannya primishen na nesamohidnih plavuchih dokah [Current state of modular formation of premises on floating docks]. Collection of scientific papers of National University of Shipbuilding. Mykolajiv. \#1. 94-99 [in Ukrainian].

Постановка проблеми. Хаусботи (з англійської "houseboat" - плавучий будинок) є відносно новим напрямом як у вітчизняному, так і у закордонному суднобудуванні. Водночас зазначені плавучі споруди швидко і міцно завоювали стійкі позиції у рейтингу продажів та надійно завоювали симпатії у любителів туризму та відпочинку на воді. Хаусботи викорис- товують у спокійних закритих водоймищах. Досить часто їх використовують для проведення гідротехнічних, науково-дослідних та інших морських досліджень і робіт, враховуючи їх достатню міцність, остійність та зручність в експлуатації [1].

Найширше розповсюдження хаусботи отримали у Нідерландах. У країні досить багато широких 
річок із незначною швидкістю течії; великий відсоток громадян віддав перевагу житлу на воді, періодично покидаючи місця стоянки та відправляючись у подорож. Через це держава навіть була вимушена вжити заходів щодо обмеження будування таких плавучих споруд [2].

В Україні зацікавленість хаусботами виникла наприкінці 2000-х років. Значною мірою це пов'язано 3 надмірними цінами на житло. Проектування та будівництво перших хаусботів в Україні проводились без урахування спеціальних технічних норм та вимог класифікаційних товариств. Склад та розміри приміщень приймалися за аналогами стаціонарних одноповерхових будівель, що не завжди враховувало специфіку експлуатації хаусбота, а також сезонність його використання. В наш час більшість вітчизняних плавучих будинків спроектовано на клас Регістру судноплавства України для річкових суден [3].

Водночас виникла необхідність у технологічній модернізації стаціонарних та плавучих споруд, враховуючи вимоги міжнародних стандартів відносно будівельних норм, що своєю чергою призвело до питання удосконалення технологій формування хаусботів, в тому числі із використанням модульних технологій. Недостатність вивчення проблеми типологічної та модульно-просторової організації побудови плавзасобів, які розглядаються, зумовило необхідність розробки нових тенденцій у методиці їх проектування, функціонального зонування та планування.

Мета дослідження. Все це свідчить про актуальність нашого дослідження та визначає мету, яка полягає у виявленні особливостей проектно-конструкторських та технологічних особливостей виготовлення хаусботів, адаптованих під водоймища України.

Відповідно до поставленої мети необхідно вирішити такі наукові задачі:

- виявити сучасні тенденції проектування та будування споруд на плавучій основі;

- провести аналіз сучасного та закордонного досвіду проектування та будування інфраструктури на плавучих спорудах;

- на основі узагальненого досвіду проектування та будування хаусботів виявити їхні типологічні особливості та створити їх класифікацію;

- виявити особливості функціонально-планувальної організації хаусботів.

Аналіз останніх досліджень та публікацій. Теоретичною базою послужили наукові роботи в галузі проектування та конструювання хаусботів, дебаркадерів, понтонів; нормативно-правова база Регістру судноплавства України, а також дослідження щодо модульного формування та конструктивнотехнологічних рішень плавучих та берегових споруд $[1 ; 2 ; 4-6]$. У дослідженні прийнято до уваги розробки М.В. Савицького та С.С. Шехоркіної, які відображають конструктивні задачі позиціонування хаусботів за допомогою якірних стійок, які водночас контролюють посадку плавучого будинку під час значних приливів та відливів, що характерно для нижньої течії Дніпра та Дунаю [4; 5].

Архітектурі та конструюванню плавучих річкових вокзалів та павільйонів присвячено праці М.С. Сленського, Б.В. Іонова, Р.Я. Хігера. Архітектурі малоповерхових будівель на воді присвячено наукові праці I.C. Еконномова, А.В. Панфілової, В.С. Баришева. В них розглянуті актуальні питання технологій формування плавучих споруд у різних умовах [6-8].

Питання залізобетонного суднобудування освітлені у працях М.Г. Слуцького, О.С. Рашковського, В.М. Коннова, О.М. Поступальсткого [9-11]. Також у дослідженні використано результати авторських розробок [12-14].

Основний матеріал (результати). Сучасний стан проектування та будівництва архітектурних об'єктів на воді досить різноманітний. У результаті аналізу різноманітних плавучих споруд та споруд на воді була розроблена відповідна типологія. До основ класифікації належать основні відмінно-конструктивні ознаки спорудження хаусботів на воді, над водою та під водою.

Ми виокремили критерії формування типових об'єктів на воді з урахуванням конструктивно-технологічних особливостей та морехідних якостей.

Плавучі основи - об'єкт має плавучість, але є несамохідним; має фіксоване постійне місцезнаходження, тобто є аналогом стоячого судна, пришвартованого до берегової споруди (рис. 1).

До таких споруд зі статичними плавучими основами відносять:

- пришвартовані будинки на основі остову судна;

- будинки на різноманітних понтонних основах;

- будинки із геометричним корпусом-понтоном;

- будинки на плотах.

Динамічні плавучі основи відрізняються тим, що об'єкт, окрім плавучості, має інші морехідні якості, а саме ходовість та керованість, тобто має можливість переміщення по акваторії самостійно або шляхом буксирування іншими суднами (рис. 2).

До споруд із динамічними плавучими основами відносять:

- катери;

- круїзні лайнери «вихідного дня»;

- плавучі лайнери-міста на воді.

До самохідних споруд із динамічною основою слід віднести:

- будинки на дебаркадерах, що буксируються;

- понтонні споруди, переправи;

- переобладнані під житло та інші функції судна та інші плавучі споруди.

Слід зазначити, що наявність на об’єктах, які розглядаються, головної енергетичної установки не передбачає переходи на велику дальність. Через це для економічної доцільності використовуються електромотори або двигуни на альтернативних джерелах енергії, які не наносять шкоди оточуючому водному середовищу, не видають шумів та прості в експлуатації. 


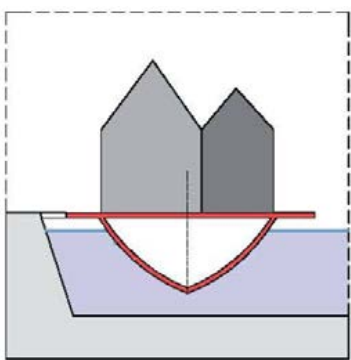

Пришвартований будинок на корпусі судна

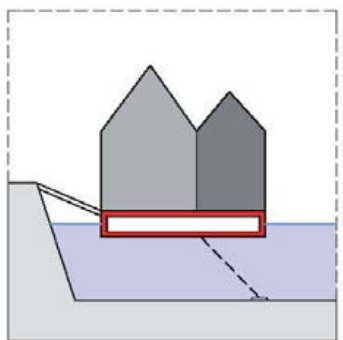

Будинок на бетонній подушці

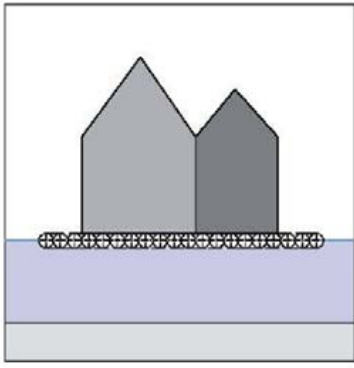

Будинок на плотах із колод

Рис. 1. Плавучі будинки із статичними основами

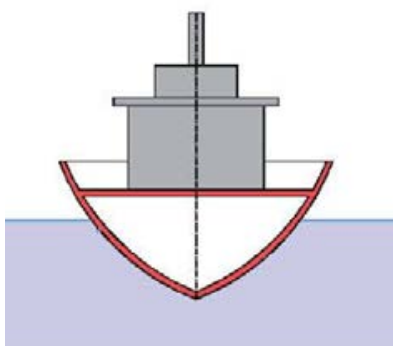

Будинок на корпусі судна

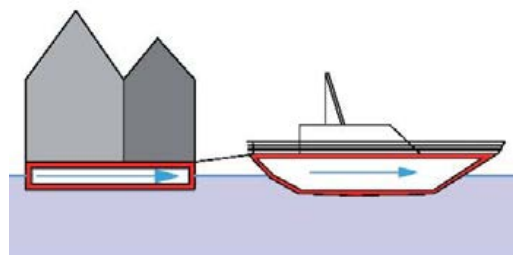

Будинок на полій бетонній подушці, який буксирується, та будинок-яхта

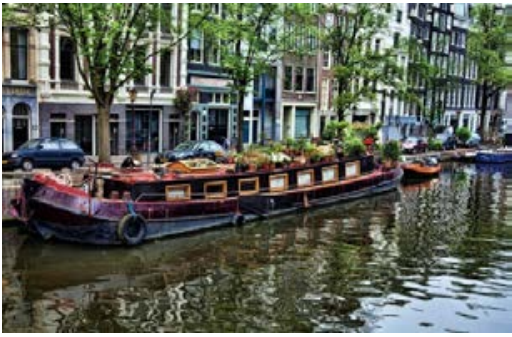

Будинок на баржі, Амстердам (http://polostroy.org/)

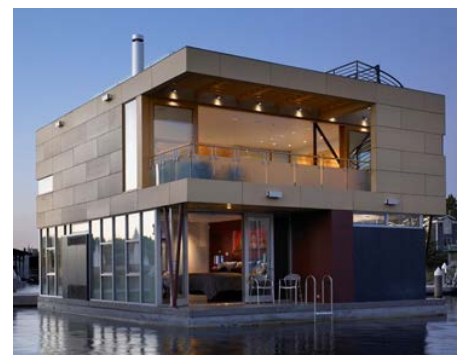

Плавучий офіс у Празі (http://radio.cz/)

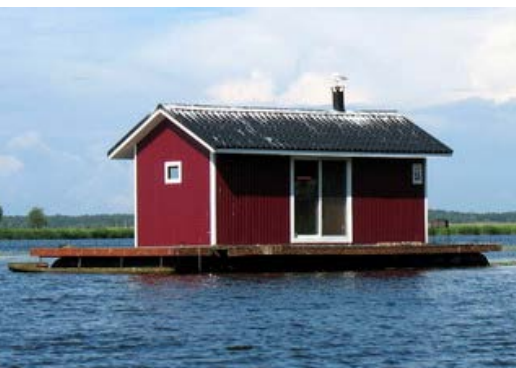

Будинок на плоту у Мельбурні (http://kultimatum.ru/)

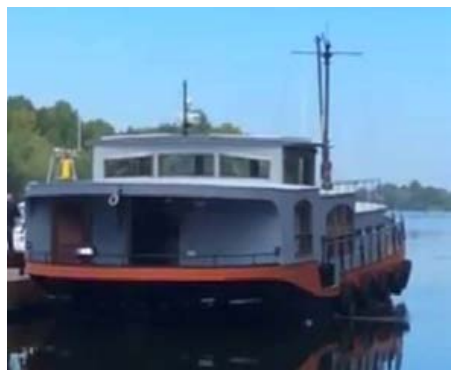

Будинок на самохідній баржі в Антверпені (http://fresher.ru/)

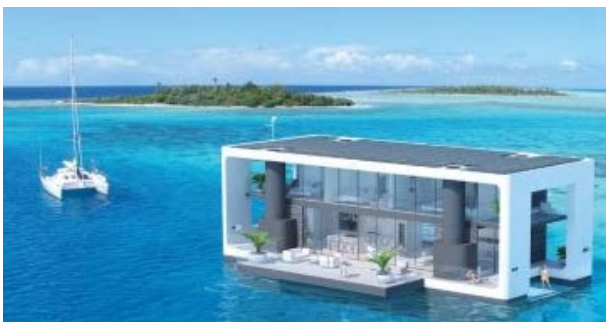

Будинок на бетонному понтоні буксирується будинком-яхтою катамаранного типу (http://techcult.ru/)

Рис. 2. Види споруд на воді із динамічними плавучими основами 
Неплавучі основи - об'єкт частково має плавучість за рахунок власних конструктивних особливостей. Неплавучі основи нараховують п’ять способів утримання на поверхні води (рис. 3).

Насипні фундаменти: об'єкт формується на штучному насипу-основі.

Насамперед робиться обв'язування груп валунів або інших більш мілких камінів на дні водоймища для використання їх у якості жорстких стержнів. Після цього шляхом намиття на них піску чи іншого матеріалу насипу-основі надається необхідна геометрична форма. Це технологічне рішення відмінно себе зарекомендувало під час створення відомих штучних островів у Арабських Еміратах. Можливі також комбінації з насипних та палевих конструкцій.

Палеві фундаменти: об'єкт має палеве конструктивне рішення для різноманітних глибин. Використання палевих конструкцій добре відоме ще 3 часів перших поселень на воді. I якщо використання стовбурів дерев як основного матеріалу раніше було єдиним рішенням, враховуючи підвищення міцності характеристик деревини у процесі взаємодії з водою, то в наш час конструктивні композитні матеріали активно витіснили традиційні. У сучасній інженерній практиці проектування стаціонарних та плавучих споруд на шельфі морів та океанів існує ряд конструкторсько-технологічних рішень, які охоплюють у собі як палеві, так і намивні технології разом із створенням шарів валунів та плит-основ. До споруд із палевими фундаментами відносять ряд висотних об'єктів на воді:

- маяки на палях;

- фортифікаційні споруди;

- житлові платформи нафтобурових установок;

- житлові платформи морських шахт;

- опори багатопрольотних мостів.

Пілонні фундаменти: об'єкт має пілонне конструктивне рішення, яке працює на міцність,

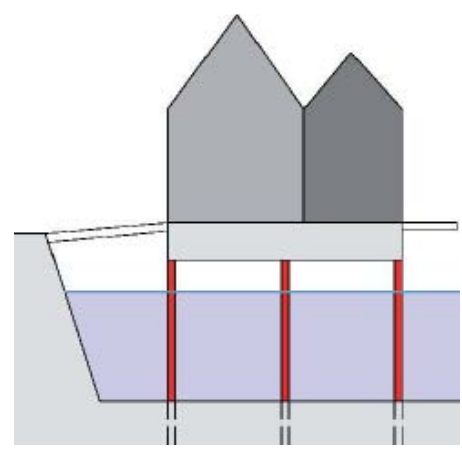

Будинок на палях

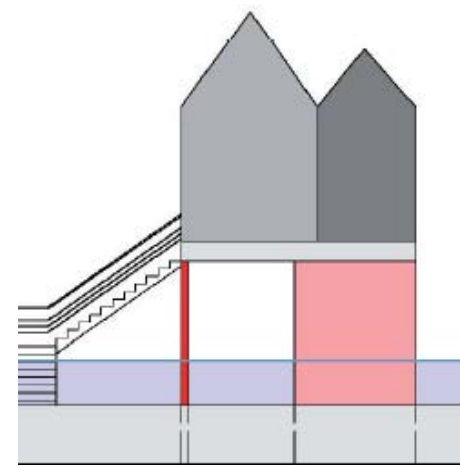

Будинок на пілонах

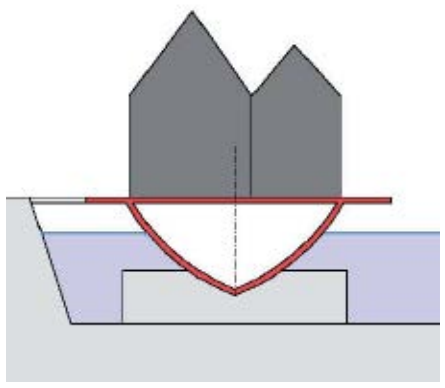

Корпус судна на бетонній основі

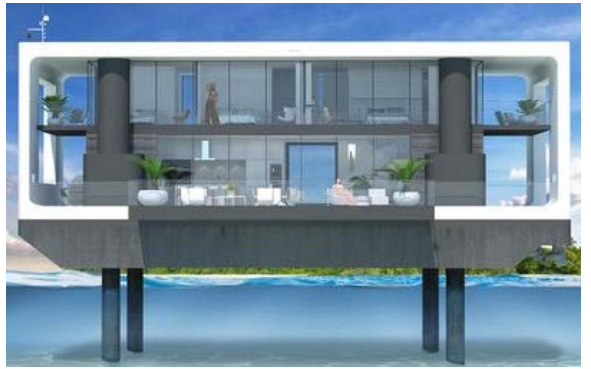

Готель на палях, острови Кука (http://robo-hunter.com/)

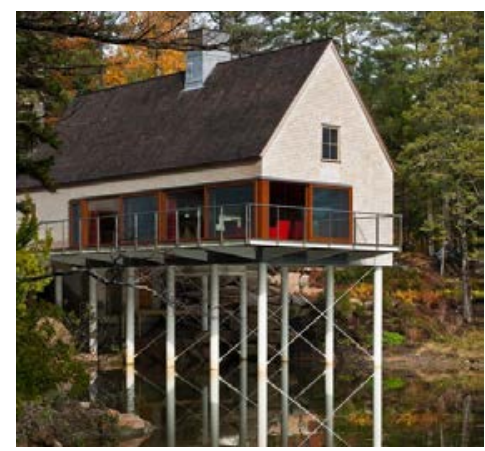

Вілла «Савой» під Парижем (http://museum-design.ru/)

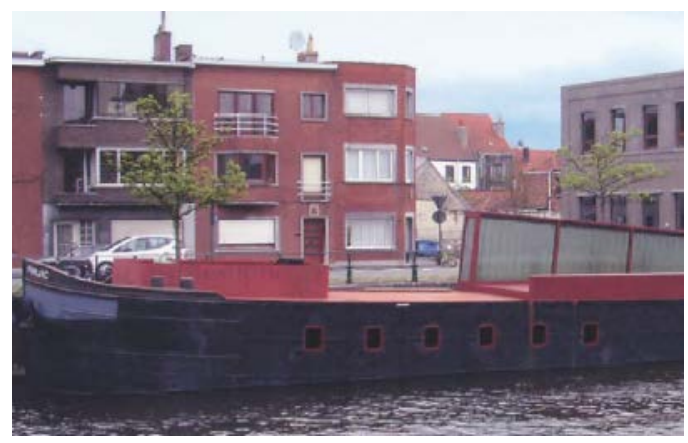

Eco-tech loftboat, Бельгія [4]

Рис. 3. Види неплавучих основ хаусботів 


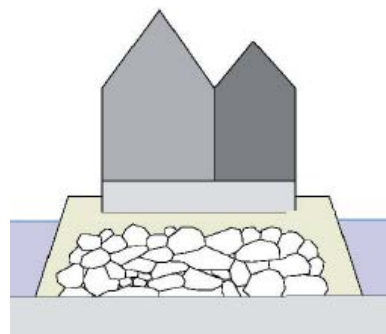

Будинок на намитій основі

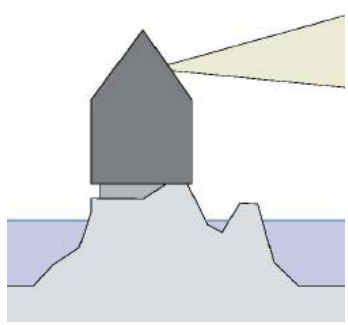

Будинок на скелевій та бетонній основах

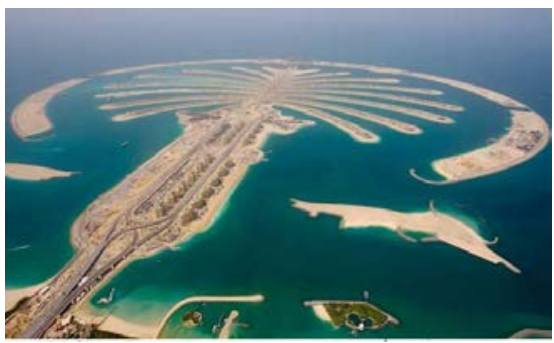

Palms Islands Resort, м. Дубаї (http://20 minutos.es/)

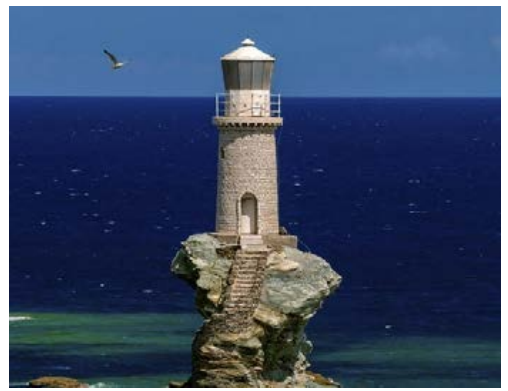

Маяк на скелі Андрос (Греція) (http://teletype.in/)

Рис. 4. Види будинків на штучних та природних морських основах

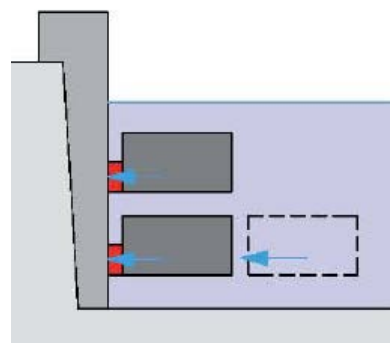

Підводні капсули приєднані до комунікацій

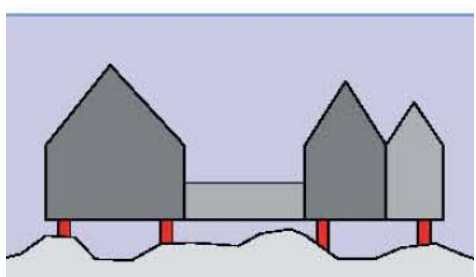

Підводні капсули-будинки на грунті водоймищ

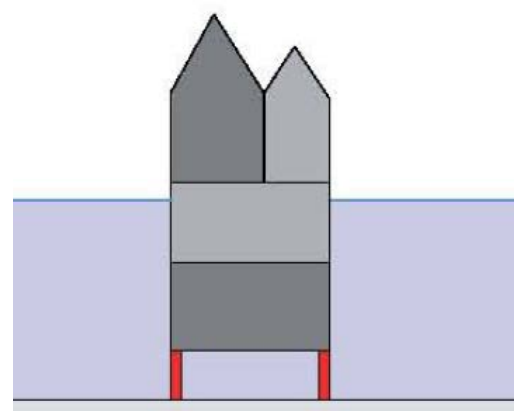

Будинок на палях із підводними поверхами

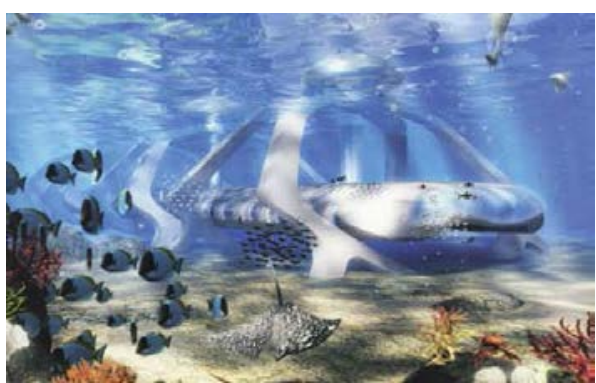

Підводний готель “Seven ocean” [7]

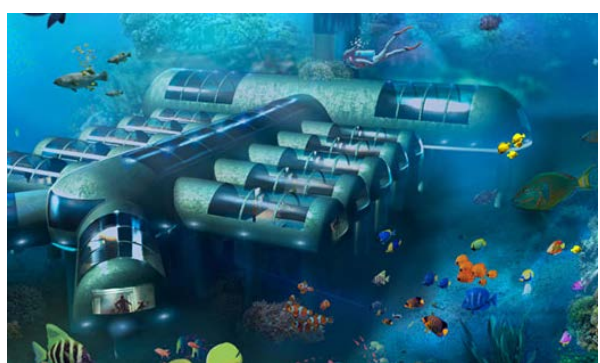

Підводний готель “Planet Ocean”, Флоріда, США (http://RuYachts.com/)

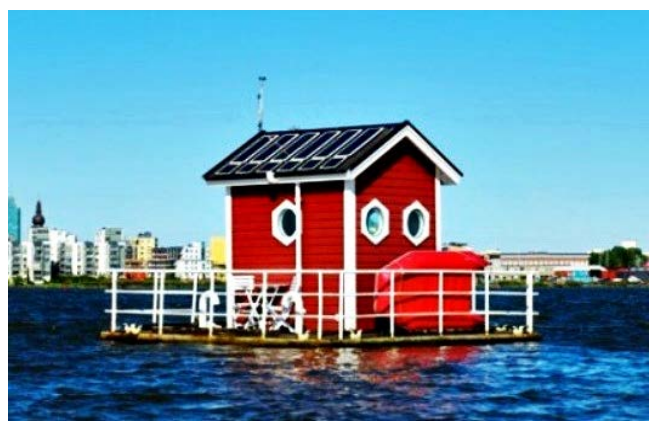

Готель “Otter Inn”, Швеція (http://OrangeSmile.com/)

Рис. 5. Статичні підводні споруди 


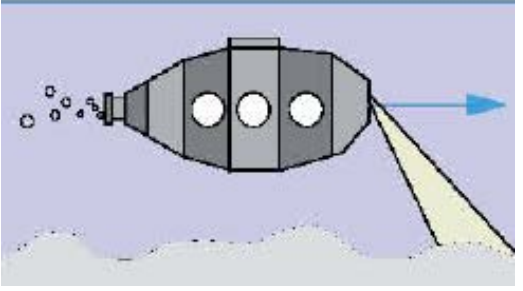

Підводні приватні субмарини

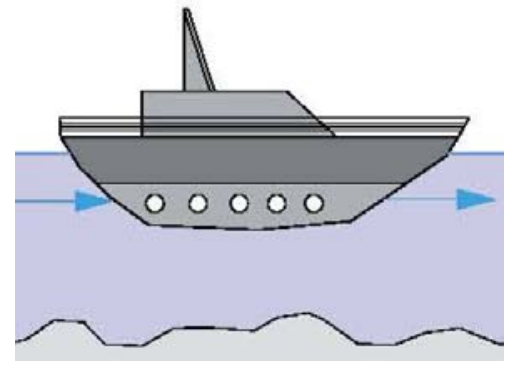

Судно-готель із підводними каютами

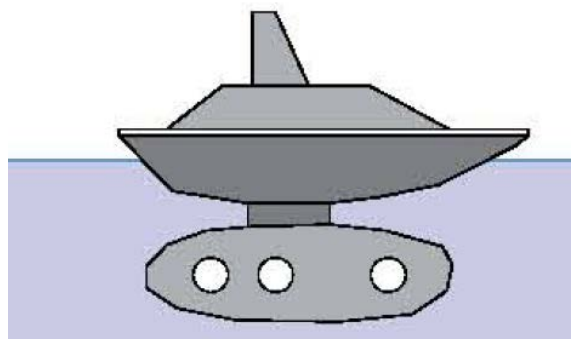

Яхта-будинок із підводним відсіком

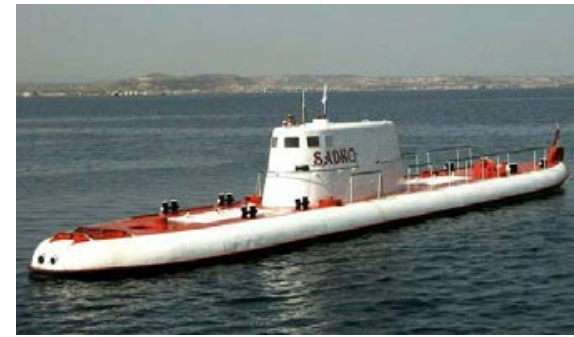

Туристичний човен «Садко», РФ (http://visacomtour.ru/)

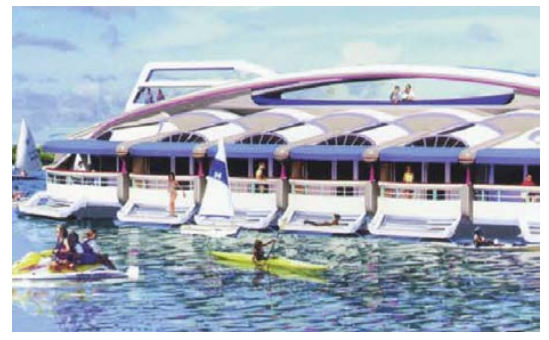

Проект готелю "Sea Venture" (фото $з$ мережі Інтернет)

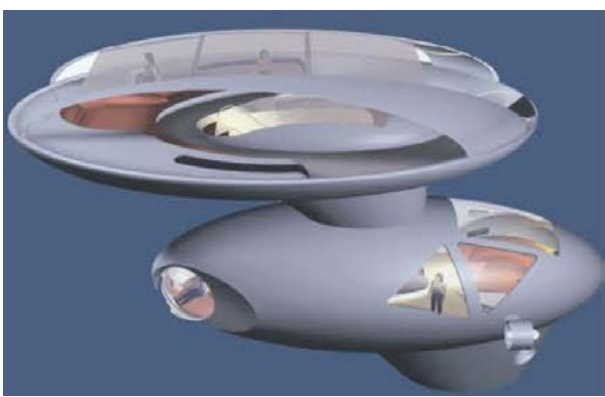

Проект "Polinarius”, Німеччина [6]

Рис. 6. Динамічні підводні споруди

жорсткість та стійкість, аналогічно палевому. Використання пілону або системи пілонів дозволяє підвищити конструктивні, функціональні та естетичні характеристики житлових та спеціальних споруд на воді. Перерозподіл навантаження несучої конструкції дає можливість функціонального зонування приміщень будинку. Сукупність пілонних та палевих конструкцій надає можливість розширення діапазону проектних рішень.

Будинки на забетонованих корпусах суден: об'єкт уявляє собою старий (який не експлуатується за призначенням) корпус судна, який з тих чи інших причин не має достатніх морехідних, міцнісних та інших якостей. Корпус судна бетонується (створюється бетонна подушка між корпусом та грунтом водоймища). Це робиться в тому разі, якщо корпус має пробоїни, конструктивні дефекти набору та/або обшивки, платформ, настилів.

Будинки на твердих природних основах: об'єкт вільно опирається на тверду кам'яну або іншого типу тверду основу. При цьому жорстка несуча властивість забезпечена шляхом комбінування бетонування плити фундаменту із твердою породою або за рахунок палевих конструкцій. Типовим прикладом можуть служити різноманітні будинки біля води на скелях, різні типи маяків, які розташовано на скелистих виступах із води, на віддаленій відстані від берега із відносно малими глибинами для безпечного проходження крупних суден та інших плавучих засобів (рис. 4).

Підводні основи - об'єкт знаходиться під водою на визначеній відстані від поверхні. Ця відстань може визначатись самим об'єктом, як, наприклад, на приватних прив'язних чи автономних субмаринах, або винятково конструкцією основного несучого підводного елементу, частини споруди під водою, до якої кріпиться чи пристиковується підводний об'єкт: герметичні капсули-люфти, апартаменти із видом на морське дно, які виготовлені використовуючи технології побудови субмарин. На сьогоднішній день $є$ два рішення із можливості перебування туристів під водою у апартаментах.

Статичні підводні споруди: об'єкт знаходиться на заданій відстані від поверхні води, має фіксоване положення за рахунок додаткових конструктивних рішень (рис. 5).

Споруда може знаходитися безпосередньо на морському дні, а доступ до них може бути реалізований винятково за рахунок інших підводних плавучих засобів, які можуть до них пристиковуватись. Споруди 


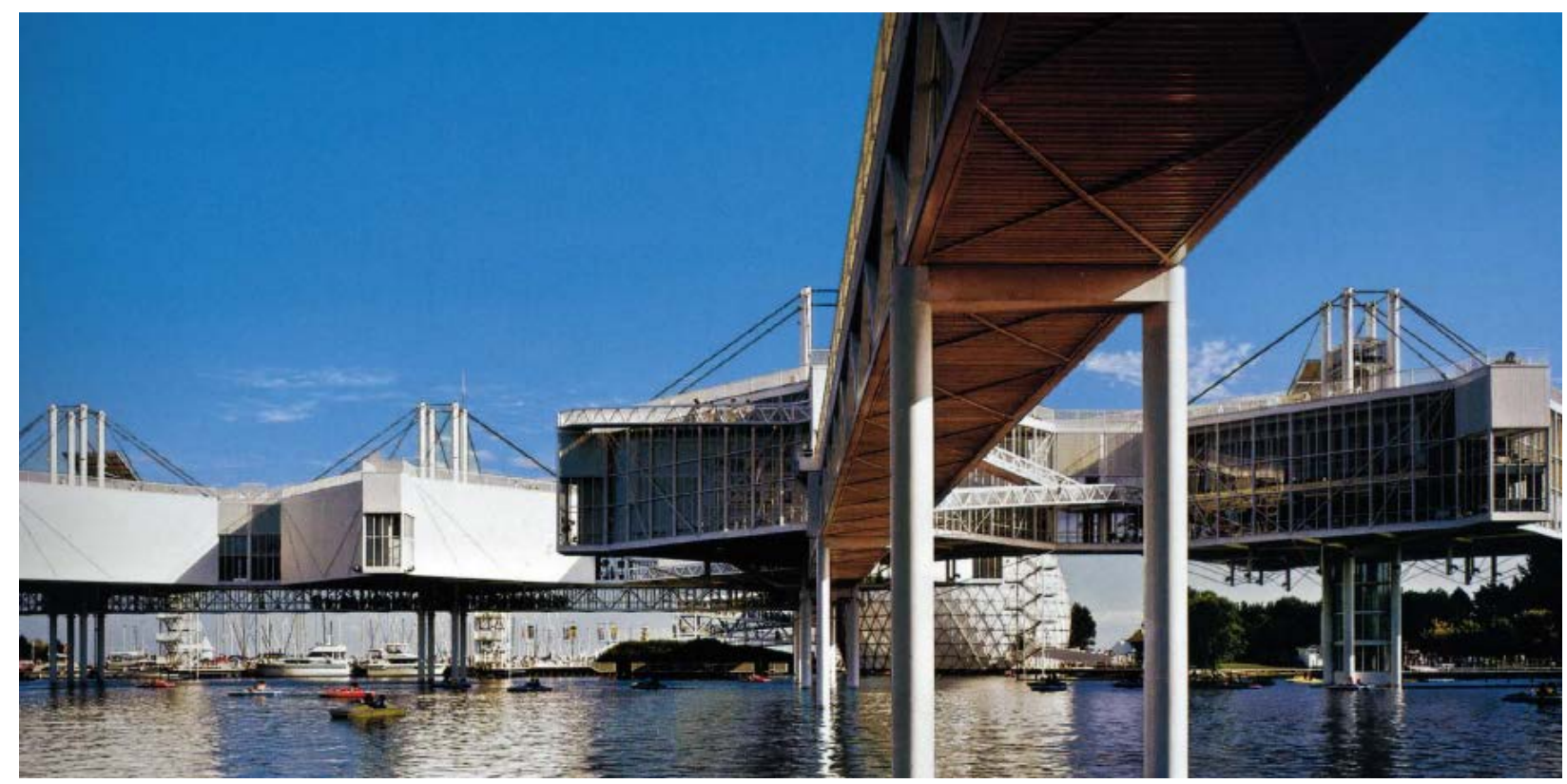

Рис. 7. Проект Еберхарда Зейдлера [7]

цього типу можуть використовуватись як науково-дослідні лабораторії, підводні готелі та бази відпочинку, але доступ до них пов'язаний із великим ризиком та вимагає початкової водолазної підготовки.

Більш раціональним рішенням є жорстке закріплення такого об' єкту до дна водоймища та при цьому формування як підводних, так і надводних ярусів. Взагалі до статичних підводних споруд можна віднести:

- різні типи підводних готелів;

- підводні ресторани;

- підводні акваріуми

- підводні музеї

- підводні навчальні лабораторії.

Динамічні підводні споруди: об'єкт повністю або частково знаходиться під водою та має можливість просторового переміщення (рис. 6).

До динамічних підводних споруд відносять:

- великогабаритні підводні плаваючі станції;

- малогабаритні підводні плаваючі засоби, батискафи, підводні човни.

Таким чином, загальна сучасна типологія підводних об'єктів на воді, у воді та під водою включають в себе:

\footnotetext{
- штучні острови;

- міста на палях;

- статичні будинки на воді;

- плаваючі будинки;

- висотні об'єкти на воді;

- будинки під водою.
}

Сучасний стан проектування, конструювання та будівництва інфраструктури на воді базується на понтонах, палях та штучних насипах. Зручна практика повторного будівництва житла з використанням списаних судів користується не меншим успіхом, ніж будівництво будинків на воді.

На рис. 7 зображено проект Еберхарда Зейдлера у місті Торонто (Канада), який уявляє собою штучний півострів із причалами для яхт та п'яти павільйонів на палях та пілонах. Побудований у 1968 1972 роках на озері Онтаріо.

ВИСНОВКИ. 3'ясовано, що у XXI столітті плавучі та водні будинки є достойною альтернативою житлових будівель «на суші» як екологічно життєздатні споруди у крупних містах. Деякі німецькі міста (зокрема Гамбург та Росток) просувають модель проживання на воді, грунтуючись на досвіді Нідерландів, запропоновуючи спосіб життя більш близький до природи.

Можливість побудови будинків на палях та понтонах у тих регіонах України, де паводки та повені мають систематичний характер (Вінницька, Хмельницька, Волинська області), є альтернативним рішенням у боротьбі з водною стихією.

Проаналізовано світовий досвід будівництва житлових споруд на воді та виявлено етапи їх формування.

Розроблено класифікацію споруд на воді, над водою та під водою залежно від типу надбудов, принципу підтримки їх на воді та способу виконання.

\section{Список літератури:}

[1] Hellweg U. Floating Homes at Rummelsburg Day in Berlin. Wasserstadt. Gamburg. 2012. p 32-38.

[2] Kendall S. Residential open building? London, E\&FN SPON, 2000. p. 23-26.

[3] Правила классификации и постройки малых судов. Киев : Регистр судоходства Украины. 2015. Том 2. 318 с.

[4] Шехоркина С.Е. Рациональное проектирование конструкций малоэтажных жилых зданий на воде : дис... канд. техн. наук : 05.23.01. Днепропетровск, 2013. 168 с. 
[5] Плавуча платформа: пат. 83103 Україна : МПК В63В 35/44. № u201302998 ; заявл. 11.03.2013; опубл. 27.08.2013, Бюл. № 16. 3 c.

[6] Экономов И.С. Принципы формирования малоэтажных жилых объектов на воде : диссертация ... кандидата архитектуры : 05.23.21. Москва, 2010. 131 с.

[7] Экономов И.С. Современные способы строительства архитектурных объектов на воде. Труды МАРХИ. Материалы научно-практической конференции (Москва, 10 нояб. 2010 г.). Москва, 2010. С. $238-244$.

[8] Koekoek M. Connecting Modular Floating Structures : A General Survey and Structural Design of a Modular Floating Pavilion URL: http://repository.tudelft.nl/view/ir/uuid:33b59201-1718-4dda-98f8-еe16d5b7c023/pdf. (дата звернення 12.11.2019).

[9] Слуцкий Н.Г. «Палада». Новые горизонты прежней специализации. Судостроение и судоремонт. Одесса. 2006. № 8. С. 8-9.

[10] Слуцкий, Н.Г., Рашковский А.С., Ермаков Д.В. Экономическая эффективность строительства и эксплуатации композитных плавучих доков большой подъемной силы. Економіка: проблеми теорії та практики : зб. наук. праць. Донецьк: ДНУ, 2007. Вип. 232, т. III. С. 614-621.

[11] Проектування, технологія і організація побудови композитних плавучих доків [Текст] : навч. посіб. / О.С.Рашковський, О.В. Щедролосєв, Д.В. Срмаков, О.М. Узлов., Миколаїв : РАЛ-поліграфія, 2015. 318 с.

[12] Щедролосєв О.В. Терлич С.В., Щедролосєв М.О. Дослідження ходових якостей плавучого будинку. $\mathrm{X}$ Міжнародна науково-практична конференція «Сучасні енергетичні установки на транспорті, технології та обладнання для їх обслуговування (СЕУТТО-2019)» (11-12 вересня 2019). Херсон : ХДМА. с. 238-240.

[13] Щедролосев А.В., Терлыч С.В. Комплексное усовершенствование технологий оборудования и отделки помещений несамоходных судов и других плавучих сооружений. Azərbaycan Dövlat Dəniz Akademiyasının Elmi Osarlari., Baky. №2, 2016. P. 50-56.

[14] Щедролосєв О.В., Терлич С.В. Сучасний стан модульного формування приміщень на несамохідних плавучих доках., Миколаїв: Зб. наук. праць НУК. 2008. Вип. 1. С. 94-99.

(C) О. В. Щедролосєв, С. В. Терлич, М. О. Щедролосєв 